\title{
Vehicle Fuel-Efficiency Choices, Emission Externalities, and Urban Sprawl
}

\author{
Kim, Jinwon
}

Publication date:

2013

Document Version

Publisher's PDF, also known as Version of record

Link back to DTU Orbit

Citation (APA):

Kim, J. (2013). Vehicle Fuel-Efficiency Choices, Emission Externalities, and Urban Sprawl. Abstract from Strategisk forskning i transport og infrastruktur, Kongens Lyngby, Denmark.

http://wwwx.dtu.dk/Sites/strategisk_transportforskning2013/Program.aspx

\section{General rights}

Copyright and moral rights for the publications made accessible in the public portal are retained by the authors and/or other copyright owners and it is a condition of accessing publications that users recognise and abide by the legal requirements associated with these rights.

- Users may download and print one copy of any publication from the public portal for the purpose of private study or research.

- You may not further distribute the material or use it for any profit-making activity or commercial gain

- You may freely distribute the URL identifying the publication in the public portal

If you believe that this document breaches copyright please contact us providing details, and we will remove access to the work immediately and investigate your claim 


\section{IRUC \\ Vehicle Fuel-Efficiency Choices, Emission Externalities, and Urban Sprawl \\ Jinwon Kim \\ DTU Transport}

This paper shows that the city where both congestion externalities and externalities from greenhouse gas emissions are corrected by efficient policies is more compact than the laissez-faire equilibrium city. Motivated by recent empirical studies showing a positive relationship between population density and vehicle fuelefficiency, the consumer is assumed to choose vehicle fuel-efficiency jointly with housing consumption and residential location. By incorporating the consumer's vehicle choice into the standard-type urban model, we can represent the total amount of vehicle emissions released by the city residents. We first establish the wellknown result that congestion externality is the source of market failure associated with excessive urban sprawl. We then claim that vehicle emissions are an additional source of market failure, which also leads to excessive urban sprawl. The source of excessive sprawl arising from emission externalities is the uses of larger and less-fuel efficient vehicles by suburban residents, which is different from that of congestion externalities. We also analyze the effect of the Corporate Average Fuel Efficiency (CAFE) regulation on the urban spatial structure. 